\title{
The Current Discussion on Austrian Family Benefits - Indicating a Major Dissensus on the Interpretation of EU Law
}

\author{
Alexander Balthasar \\ Andrássy University Budapest, Hungary \\ alexander.balthasar@andrassyuni.hu
}

Received: 18. 5. 2020

Accepted: 30. 10. 2020

\section{ABSTRACT}

In early 2018, Austria amended its family benefits law by introducing 'indexation' according to the average living costs of the country where the child actually resides. What seems to be, at first sight, a flagrant breach of EU law (in particular of Article 7 of Regulation [EC] 883/2004) is, when looking deeper, much more complicated and might very well be only a symptom of deeply rooted differences in the interpretation of current, post-Lisbon Union law,

(i) in particular with regard to the relationship between the traditional prohibition of "discrimination on grounds of nationality" (Article 18 TFEU, Article 21(2) CFR; the 'Leitmotiv' of the Treaties) and the "citizenship of the Union" (Article 9 second sentence TEU, Article 20(1), first and second sentence) on the one hand and the further role of the "nationality of a Member State" on the other, which shall, pursuant to Article 9 TEU, third sentence, as well as Article 20(1) TFEU, third sentence, not be replaced by the "citizenship of the Union",

(ii) but also with regard to Article 352 TFEU, the scope of which is, most probably, much smaller than that of its predecessor, Article 308 TEC,

(iii) and last but not least, with regard to a proper understanding of the principle of equal treatment, requiring not to treat alike factually different situations.

Giving a full picture not only in abstract terms but demonstrating the relevance of the said differences on the concrete example of the interpretation of the above mentioned secondary legislation, the author aims at contributing to bridging gaps and, thus, fostering a better mutual understanding as a vital precondition for the future legal cohesion of the EU.

Keywords: family benefits, citizenship of the Union, nationality, principles of equal treatment/non-discrimination, rights of the child, principle of conferral, Treaties amendment clauses, assessment of validity of EU law 


\section{Starting point: Facts, bewilderment, items to be discussed}

\subsection{The facts}

As it is quite well known, the Austrian government formed in December 2017 on the basis of the result of the general elections held on 15 October 2017 - the so called "turquoise-blue" coalition (of reformed Christian Democrats with chairman - and Austrian federal chancellor Sebastian Kurzand right wing populists, then with chairman - and then Austrian federal vice-chancellor Heinz-Christian Strache) - had aimed right from the beginning at an "assessment of" the possibility of an „indexation of family benefits" - i.e. of specific State allowances destined to support the maintenance of children ${ }^{1}$, consisting in an adjustment to the real costs of life of the respective child in the respective EU Member States, „in conformity with EU law".

Fairly one year later, on 4 December 2018, an amendment of the Family Benefits Act, via insertion of a new paragraph 8a, was published in the Federal Law Gazette (Art 1, point 1 of the Federal Act BGBl I 2018/83) and came into force the day after. In essence it was provided that since 1 January 2019 for all those children

- living abroad (i.e. in another EU Member State or in a State of the EEA or in Switzerland

- the carers of whom nevertheless were entitled to receive the Austrian Family Benefit

the actual amount of this benefit had to be fixed on the basis of the "comparative price levels" issued by EUROSTAT. By this means of an indexation, „effects of distortion" occuring when the said benefits were „exported without proper distinction" were to be avoided. ${ }^{3}$

From the "specific information" and the related, very detailed and elaborated argumentation given on (all the) five pages of the the Explanatory Memorandum ${ }^{4}$, we learn that the government when proposing this amendment to Parliament was fully aware that, at least at that point in time, more EU lawyers than not held firmly that such an indexation was against EU law, but did not share this mainstream opinion. ${ }^{5}$ How sensitive the issue was may be inferred from the fact that already six weeks after publication the European Commission started the first step of an infringement procedure, Marianne Thyssen, then Commissioner for Employment, Social Affairs, Skills and Labour, saying:

1 In fact this benefit has never been based on a specific federal competence allowing or even mandating State measures in the favour of families as such, but on Article 10 (1) (17) of the Austrian Constitution („Bevölkerungspolitik“ = demographic measures"). This difference is now relevant, see infra fn 102.

2 See the Coalition Programme (2017), 116.

3 Cf the Explanatory Memorandum (RV 111 Blg NR XXVI. GP), 1: „main considerations “.

4 See previous fn.

5 Or, to put it differently: the aim of the government was not to disregard EU law but to strive for a different interpretation. 
"Our single market is based on fairness and equal treatment. There are no second-class workers in the EU. When mobile workers contribute in the same way to a social security system as local workers, they should receive the same benefits, also when their children live abroad. There are no second-class children in the EU." ${ }^{16}$

Austria replied in March 2019; after "[h]aving thoroughly analysed the arguments put forward by Austria, the Commission ... concluded that the concerns ha[d] not been addressed. Therefore, the Commission ... moved to the second step in the infringement procedure with a reasoned opinion" in late July 2019. ${ }^{7}$

End of October, the Commission had received the Austrian answer to this "reasoned opinion"8 - this time no longer of the "turquoise-blue" coalition, but by the post Ibiza transitory government which, nevertheless, maintained the position of the former government (as does, up to now, the in early January 2020 newly formated current "turquoise-green" coalition). From that point in time on it took more than half a year until the Commission decided, on 14 May 2020, to refer the matter to CJEU under Article 258 TFEU. ${ }^{9}$

\subsection{Questions}

This is striking in particular because also when taking other, contingent factors into account ${ }^{10}$ we should not have thought bringing this matter to the Court of Justice would raise any difficulty; right to the contrary, it could have been lodged quite easily still in the very last "infringement package" of the Juncker Commission end of November. ${ }^{11}$ Moreover, it would have sufficed to refer bluntly to Article 7 of Regulation (EC) 883/2004 ${ }^{12}$, stating: „Waiving of residence rules. Unless otherwise provided for by this Regulation, cash benefits payable under the legislation of one or more Member States or under this Regulation shall not be subject to any reduction, amendment, suspension, withdrawal or confiscation on account of the fact that the beneficiary or the members of his/her family reside in a Member State other than that in which the institution responsible for providing benefits is situated. " ${ }^{13}$, the more so,

6 See EC Press Release of 24 January 2019; emphasis added.

7 Cit EC Press Release of 25 July 2019; the personal statement of Commissioner Thyssen forming part of this release sounded quite the same as her statement of January („Equal treatment is a fundamental principle of the EU. EU citizens, who work in another Member State than their own and pay taxes and social security contributions, have a right to the same family benefits."

8 CF ORF (29 October 2019).

9 The No of this infringement decision is 20182372.

10 Mainly, we may consider two events:

(i) On 30 November 2019 the term of office of the Commission Thyssen formed part of ended

(ii) Since February 2020, whole Europe has suffered from the Corona crisis.

11 CF EC Presse Release of 27 November 2019.

12 OJ L 166, of 30 April 2004, 1.

13 This item is addressed in the EC's Press Release of 14 May 2020, in the following paragraph: „Member States may not reduce the amount of any cash benefit granted to persons insured under their legislation for the sole reason that these persons or their family members are residing outside their territory. The Austrian indexation mechanism reduces the amount of family benefits and child tax credit granted for children residing in an EU Member State where the cost of living is considered to be lower." 
because the Austrian "family benefits" do not form part of Annex X (referred to in Article 70 (2) (c) and having the effect of exempting the benefits listed there from the scope of Article 7$){ }^{14}$

In contrast, there was no need at all to address fundamental or primary law considerations as mentioned by Commissioner Thyssen ${ }^{15}$ or by the Austrian government in the said Explanatory Memorandum, or to add now a consideration like the following:

"The fact that another Member State is considered to have lower cost of living than Austria is of no relevance for a benefit, which is paid out as a lump sum and is not linked to the actual cost of maintaining a child. In addition, Austria does not apply the indexation mechanism to persons working abroad for an Austrian public authority, whose children also reside in another EU Member State. " ${ }^{16}$

Nor was it necessary to refer - as it was done now in the referral to CJ - in addition also to Regulation (EU) No 492/2011 ${ }^{17}$, in particular to Article 7 (2), stating that "[a worker who is a national of a Member State]" posted "[in the territory of another Member State] ... shall enjoy the same social and tax advantages as national workers."

So we face at least three questions:

- Why did the Commission having been so sure already in January 2019 that the Austrian amendment would infringe even fundamental principles of EU law need so much time to refer the question to $\mathrm{CJ}$, although at least infringement of Article 7 of of Regulation (EC) 883/2004 had always been evident?

- Why did Commissioner Thyssen not confine herself to state the obvious the infringement of EU secondary law - but find it necessary to reach out to fundamental considerations?

- Why did the Austrian government(s) - aiming explicitly to act in conformity with EU law - nevertheless dare to neglect the obvious infringement of EU secondary law?

\subsection{The specific context of „Brexit “}

Of course, we should not overlook the short-term political context: Still in early 2016 the very same Commission Thyssen formed part of had committed itself, in the very specific political context of "Brexit" ${ }^{18}$, to "make a proposal to

\footnotetext{
14 See, however, infra section IV/C/(ii).

15 Cf now also the following paragraph in EC's Press Release of 14 Ma 2020: „Further, the principle of equal treatment in social security coordination matters means that persons must be treated equally without distinction of nationality, by abolishing discriminatory measures in national legislation."

16 Cit EC Press Release of 14 May 2020.

17 OJ L 141, 1.

18 The elaboration of this proposal formed (as lit e) part of the "arrangements" which should "become effective on the date the Government of the United Kingdom informs the Secretary-General of the Council that the United Kingdom has decided to remain a member of the European Union“, EC considering these „arrangements" constituting „an appropriate response to the concerns of the United Kingdom."
} 
amend Regulation (EC) No 883/2004 ... on the coordination of social security systems in order to give Member States, with regard to the exportation of child benefits to a Member State other than that where the worker resides, an option to index such benefits to the conditions of the Member State where the child resides. The Commission considers that these conditions include the standard of living and the level of child benefits applicable in that Member State. ${ }^{19}$

Although obviously envisaged as elements of bargaining and, thus, not entirely free from ad hoc tactics,

(i) not all of these "arrangements" ${ }^{\prime 20}$ were meant as mere exceptions for the UK, in particular, not the amendment of Regulation (EC) No 883/2004 which was intended to apply to all Member States

(ii)no "arrangement" was considered to need a modification of Primary Law, right to the contrary, European Council itself had assessed all elements of the project being "fully compatible with the Treaties. ${ }^{.21}$

\subsection{Items of discussion}

Exactly this assessment of both the European Council and the European Commission, however, indeed conversely raises severe doubts with regard to the specific relationship of the regulation at issue as it stands now with current (postAmsterdam, in particular post Lisbon) EU primary law. These doubts which shall be discussed here in more detail (section II) - may have indeed prevented the European Commission from referring the matter to $\mathrm{CJ}$ - until a reference by an Austrian court (the Federal Tax Court - „Bundefinanzgericht“) ${ }^{22}$ carried the risk of a full assessment of the regulation at issue with current primary law by $\mathrm{CJEU}^{23}$, thus making it advisable, from the Commission's perspective, to balance this reference by a reference of its own. ${ }^{24}$ Besides, the Commission might have realized

Clearly enough, the Commission could not be amused when, still before the "Brexit" had materialized, another Member State tried to realize on its own initiative one of these „arrangements", thus devaluing the bargaining package. On the other hand, now, after the Brexit, at least this specific interest is obsolete.

19 Cit Annex V („Declaration of the European Commission on the indexation of child benefits exported to a Member State other than that where the worker resides") to the EC's Conclusions (18/19 February 2016).

20 See supra previous fn but one.

21 Cit section I/2 of the Conclusions (18/19 February 2016).

22 Decision of 16 April 2020, RE/7100001/2020. On pages 14 et seq (under the heading „Richtige Anwendung des Unionsrechts nicht offenkundig") not only a chronology of the political deliberation process, but also a survey of the Austrian doctrine assessing (mainly sceptically) the conformity of the Austrian legislation with Union law is given.

23 While being perfectly true that the Austrian court's reference did not yet explicitly address the questions raised here (so that CJ which lacks, in contrast to Austria's Constitutional Court, the competence to start the assessment of Article 267 (1) (b) TFEU on its own motion, is still not entitled to go in medias istas res), it is quite probable that this issue would be discussed in the further course of the proceedings, in particular during an oral hearing, and thus, eventually, provoke an explicit reference in that regard, too.

24 As it is well-known there is a remarkable difference between an infringement procedure (Article $258 \mathrm{f}$ TFEU) and a reference procedure (Article $267 \mathrm{TFEU}$ ): while in the former it suffices to establish a breach of EU secondary law, in a reference procedure (Article 267 TFEU) CJ also the conformity of secondary law with primary law is an issue; it is here where CJ might have to 
- the specific construction of the Austrian family benefits system against the backdrop of the EU Regulation system and, consequently

- the fact that the Austrian model is still a quite moderate one, compared with the opportunities provided by the Regulation itself.

These considerations - backed by the insight that the current Austrian position, although only quite recently adopted, is not at all an idiosyncratic peculiarity negating European values, but had, right to the contrary, even in the pre-Amsterdam era been European mainstream for decades (section III) will be developed here in more detail (section $I$ ).

When scrutinizing this topic my intention is a double one (both elements enshrined likewise in Article 2 TEU):

- On the one hand it is already in general - under the paradigm of the principle of the rule of law requiring a homogenious "hierarchy of norms" - really vexing that lower ranking norms should not fully comply with higher ranking law

- On the other hand, however, the democratic principle in particular seems to require scrupulous endeavour that EU secondary law continues to comply with primary law, given the fact that EU primary law has been produced by the consent of all Member States and is, thus, democratically best qualified.

\section{The specific relationship of Regulation (EC) 883/2004 with current EU primary law}

\subsection{Competence of the EU?}

\subsubsection{The primary law framework}

The Regulation is based „in particular" on "Articles 42 and 308" of the EC Trea$\mathrm{ty}^{25}$, admitting - of central interest with regard to our topic ${ }^{26}$ - "The Treaty does not provide powers other than those of Article 308 to take appropriate measures within the field of social security for persons other than employed

declare the respective secondary law norm invalid (under paragraph 1 [b]; cf CJ Judgment of 6 October 2015, C-362/14, Schrems, points 60 et seq, 106). This declaration, however, would, at least de facto, amount to an annulment, see not only Edward/Lane (2013), point 5.142, but already the Opinion delivered in Case 359/87, Pinna II, points 13 et seq, 41 (by analogy "). Hence, a parallel referral by the Commission offers at least a practical chance that both procedures (in particular when combined to a common procedure) focus more on the surface, i.e. the question of conformity with secondary law, leaving the validity issue in the shadow.

It may be added that Member States do not dispose of a direct opportunity to refer to CJEU when, as it has been the case with Austria in the situation at issue, they come to doubt whether a piece of secondary law is (still) fully in line with primary law. From this perspective, the strict time limit barring any complaint under Article 263 TFEU later than two months after publication really runs short of the principle of the rule of law, forcing Member States to adopt first national legislation which might infringe EU secondary law, but be fully in line with primary law, instead of being able to initiate a clarification of the legal situation beforehand by the competent court, the CJEU.

25 Cit recital 1 of the regulation.

26 As outlined supra we deal here only with allowances made for the sake of children of employed persons, not for the employees'own sake. This fact is of crucial importance also from a second perspective, see in more detail infra section 2.2. 
persons." While making use of this clause - although softening and, thus, being in a "fundamental tension" 27 with the „principle of conferral" enshrined in Article 5 (1) TEU - was perfectly legal in the pre-Lisbon world ${ }^{28}$, the postLisbon assessment is, most probably, different with regard to the insertion of Article 48 (6) (3) TEU, running: „The decision referred to in the second subparagraph shall not increase the competences conferred on the Union in the Treaties." Is it really conceivable that EU might increase its competences by a decision based on Article 352 TFEU whereas to achieve exactly this effect via the more complicated procedure ${ }^{29}$ under Article 48 (6) TEU has been explicitly prohibited? $?^{30}$ In CJ's Judgment of 26 September 2013, C-431/11, UK/Council, point 17, we read: „On 10 March 2011, the Commission submitted an amended proposal in order to change the legal basis cited. According to the explanatory memorandum to that proposal, as the Lisbon Treaty had extended the competence set out in Article 48 TFEU to self-employed migrant workers, Article 352 TFEU was no longer necessary as a legal basis." That statement is a clear indication that the purpose of Article 352 TFEU is "to extend the competence" of the EU in cases where no Treaty basis is available - thus pretty much the same what the term "increase" used in Article 48 (6) TEU means. ${ }^{31}$ Now it is true that CJ accepted, in its Opinion No 2/94 of 28 March 1996, point 30, Article 308 EC Treaty (or, more precisely, then still, in the pre-Amsterdam version, Article 302 EC Treaty), the predecessor of Article 352 TFEU, as „an integral part of" the "institutional system based on the principle of conferred powers", thus discerning it on the one hand from the use of an "implied power" (point 29), on the other hand from an Treaty amendment (point 30). When assessing the current relevance of this Opinion properly we have, however, to take into account that (i) at the point in time when the Opinion was delivered there didn't yet exist "simplified revision procedures", so that the scope of Article 302 (308) EC Treaty was to be compared with what is now called the "Ordinary" Treaty „revision procedure" (ii) that the aforementioned prohibition of "increas[ing] the competences" is now enshrined in Article 48 (6) TEU, governing the newly created category of "simplified revision procedures."

Both elements taken together seem to indicate that the Lisbon Treaty, by inserting Article 48 (6) (3) TEU, has exactly prohibited what before had been the very purpose of Article $308 \mathrm{EC}$ Treaty. If, however, this finding is correct there are very good reasons to assume that Article 352 TFEU, although itself amended (by adding limitations in the newly created paragraphs $2-4^{32}$ ) has

27 Cit Irmscher (2019), point 1718.

28 For the limits cf CJ's Opinion of 28 March 1996, No 2/94 (referred to in more detail infra in the main text).

29 Whereas the procedure under Article 352 requires in essence only a unanimous decision of the Council of the EU, Article 48 (6) TEU needs not only a unanimous decision of the European Council, but also an adoption „by the Member States in accordance with their respective constitutional requirements".

30 Cf for the opposite view already Balthasar-Wach (2020), 342; Balthasar (2017), 203, fn 143a. See also Edward/Lane (2013), points 6.52 et seq, in particular 6.54.

31 At least in the German version both documents referred to here use the very same term "ausgedehnt" bzw „Ausdehnung".

32 CF Edward/Lane (2013), point 6.52. 
no scope of application at all any more, at least not in the meaning of former Article 308 EC Treaty. ${ }^{33}$

\title{
2.1.2 Consequences for Regulation (EC) No 883/2004
}

Whereas Regulation (EC) No 883/2004 was adopted and entered into force long before the point in time when Article 48 (6) TEU entered into force on 1 December 2009, the Regulation nevertheless only applied from 1 May 2010 on, when the Implementing Regulation (EC) No 987/2009 - adopted on 16 September $2009^{34}$ entered into force. ${ }^{35}$

The Implementing Regulation itself, however, is based, in the same way as the Founding Regulation, i.e. Regulation (EC) No 883/2004, on Article 308 EC Treaty. If the reasoning presented supra is correct, then those parts of the Founding as well as of the Implementing Regulation based on Article 308 EC Treaty lacked a sufficient Primary law basis already from the very beginning of their actual operability.

Now it is settled case-law that „[t]e (appropriate) legal base of a measure must be in force at the moment of its adoption"36 But apparently when using this term, CJ did not have in mind to favour the moment of mere "adoption" to that one of the actual "entry into force" or even an even longer postponed start of "application"; right to the contrary, it held in its Judgment of 4 April 2000, C-269/97, Commission/Council, point 45:

\begin{abstract}
"Community measures must be adopted in accordance with the Treaty rules in force at the time of their adoption. It would be contrary to the principle of legal certainty if, in determining the legal basis of such a measure, account were to be taken of an alleged development in relations between institutions which does not yet find confirmation in any provisions of the Treaties currently in force or in the provisions of a treaty which has not yet entered into force."
\end{abstract}

This language fosters the assuption that in case of a discrepancy betwen the mentioned three points in time („adoption“, „entry into force“ and „application") as it is the very essence of any "legisative vacancy" the moment of the

33 The main counter-argument against the most radical assumption (that no scope at all was left) being, of course, that this result would counteract the intention of the "Masters of the Treaties" to keep this provision, I see a perfectly viable way out: why not accept Article 352 TFEU as an explicit Treaty basis for the former doctrine of "implied powers" (still referred to in CJ's Opinion No 2/94, point 29) or of applying „analogy“ in order "to fill the gap" (cit Opinion no 2/94, point 29) in case of, in Austrian legal positivism, so-called „purely technical“ "lacunas" (cf Walter [1972], 95 et seq)?!

34 OJ L 286, of 30 October 2009, 1. Is it really pure coincidence that this Implementing Regulation was, after five years of preparation, still adopted only less than three months before the entry into force of the Lisbon Treaty - or is this already an implicit admission (at least: worry) that adoption under post-Lisbon rules would no longer be possible?

35 Article 91 (2) of Regulation (EC) No 883/2004 read in conjunction with Article 97 of Regulation (EC) No $987 / 2009$.

36 Cit Edward/Lane (2013), point 6.49, with references in fn 303; see also CJ's Judgments of 28 July 2011, C-309/10, Agrana, with references in point 31, of 3 September 2015, C398/13 P, Inuit, with references in point 22, and of 10 September 2019, C123/18 P, HTTS, with references in points 37, 39; Opinion of 18 January 2018 delivered in case C-528/16, Confédération paysanne, point 132, with references in fn 40. 
beginning of the actual operability (i.e. when the status of being "currently in force" has been reached) would prevail. ${ }^{37}$

If that is true, however, the necessary implication would be that (i) the Implementing Regulation had to be declared „invalid" under the procedu-re of Article 267 TFEU $^{38}$ with regard to those parts based on Article 308 EC Treaty, (ii) already by this invalidation all parts of the Founding Regulation based on the same legal ground - among those, as said, in particular also the provisions concerning family benefits would become inoparable; (iii) what is more, the same reasons sufficient for invalidating parts of the Implementing Regulation would likewise apply also with regard to the respective parts of the Founding Regulation. ${ }^{39}$

\subsubsection{Consequence for Regulation (EU) No 492/2011}

In contrast to Regulation (EC) No 883/2004, Regulation (EU) No 492/2011 is not based on Article 352 TFEU. ${ }^{40}$ This fact has to be taken into account when interpreting Article 7 (2) reg cit referred to by the Commission ${ }^{41}$. „Social and tax advantages" must, therefore, not include benefits the prescription of which would require to be based on Article 352 TFEU, as it is in particular the case with "family benefits" regarding a posted worker's family members residing in another Member State.

This finding (that "family benefits"are not covered at all by Article 7 [2] of Regulation [EU] No 492/2011) is, by the way, backed by "Section 10“, where, under the heading "workers' families", we read: „Article 10.

The children of a national of a Member State shall be admitted to that State's general educational, apprenticeship and vocational training courses under the same conditions as the nationals of that State, if such children are residing in its territory...."

\section{Because}

- on the one hand, we find no allusion whatsoever to "family benefits" in this section (which is, compared with the general Article 7, lex specialis)

- on the other hand, exactly the condition that a Member State is responsible for children of a posted worker only insofar as they reside on its territory, is explicitly stated here.

37 At this stage of deliberation I fully neglect the consequences which might arise when the newly emerged discrepancy between the "settled case-law" discussed here and the oppsite view adopted with regard to the applicability of the EU Charter of fundamental rights (see infra lit $\mathrm{B} / 2$ ) is realized.

38 See supra fn 24.

39 The only, slight difference between the two regulations is that the Implementing Regulation entered into force after 1 December 2009, whereas the founding Regulation, although having entered into force prior to this date was only applicable after this date.

40 The preamble mentions only, although mitigated by an „in particular“, „Article 46" TFEU.

41 See supra section I/B. 


\subsubsection{Conclusion}

There are at least very good reasons to assume that not only Regulation (EU) No 492/2011 is not at all to be applied to the family benefits here at issue (i.e. regarding children not residing in the territory of the Member State called on), but that to the very same extent also the application of the Founding Regulation (EC) 883/2004 as well as of the Implementing Regulation (987/2009) runs counter the post-Lisbon primary law and, thus, had to be declared invalid in a reference procedure under Article 267 (1) (b) TFEU.

\subsection{Compatibility with Article 24 of the EU Charter of Fundamental Rights?}

\subsubsection{Obtaining family benefits: right of the child or right of the carer?}

If, however, contrary to what was suggested in section 2.1 , the regulations at issue disposed in fact of a sufficient legal basis in the Treaties, , they had still to comply with EU fundamental rights, now in particular enshrined in the Fundamental Rights Charter (CFR), too. ${ }^{42}$

With regard to our topic: family benefits, meant to facilitate the maintenance of children - is of crucial interest Article 24 CFR, its first sentence (of paragraph 1) starting with:

„Children shall have the right to such protection and care as is necessary for their well-being."

The main added value of this provision is to underline the position of "children as independent rights holders ... rather than mere „objects of ... law. " ${ }^{43}$

Already this perspective is not met by the EU regulations at issue ${ }^{44}$, because the right to obtain the "family benefit" is not perceived at all as a right of the respective child him-/herself, but only as one of - roughly speaking - his/her carer. ${ }^{45} \mathrm{Or}$, to be more precise: what is really lacking is to make a difference between those kinds of "family benfits" which

(i) form, in one way or the other, part of the salary of a carer or are at least, in particular via an insurance system, dependent of the status of an economically active person and those which

42 Although the Founding Regulation refers several times to the "[principle of] equal[ity of] treatment" (see recitals $8,17,43$ ), its preamble does not yet contain a fully-fledged fundamental rights compatibility clause (since the relevant policy of the Commission, although having already started in 2001, commenced only in 2005, see Benoit-Rhomer [2011], 30; cf also De Schutter [2011], 124 et seq), nor does the Implementing Regulation (!).

43 Cit Lamont (2014), points 24.39 (emphasis added), see also Fuchs (2019), points 18, 22, and Hölscheidt (2019b), point 18.

44 Also the Austrian law falls still short of this requirement, although only slightly (see infra text by fn 107).

$45 \mathrm{Cf}$ Article 67 reg cit. This is still a major flaw also in other related fields, e.g. in the „Brussels Ila Regulation" (Regulation [EC] 2201/2003, as amended by Regulation [EU] 2019/1111), cf Balthasar-Wach (2020), 63 et seq, 278 et seq, 409). 
(ii)are handed over by the State (either directly to the child or, still more frequently, to the carer with a clear obligation to use this allowance for the benefit of the child only).

While within the first category it is perfectly correct to construe the obtaining of the "family benefit" as a right of the recipient of the salary (within the horizontal relationship of the employer and the employee ${ }^{46}$, governed, at least to a large extent, by the principle of private [individual or collective] autonomy ${ }^{4}$ ) or of the insured person (in his/her relationship to the insurance, which is, dependent on the status of the owner of the insurance, of a horizontal or of a vertical kind), it is totally different within the second category: Even if here the direct recipient of the family benefit should still be the carer, it is clear that, from a fundamental rights perspective, in this paradigm the carer can only serve as a trustee while the real addressee of the social policy measure being always and only the child.

\subsubsection{Assurance: applicability of the Charter?}

But: given the entry into force of the CFR only, as part of the Lisbon Treaty, on 1 December 2009: which relevance can have a Charter provision with regard to the regulations at issue? At first sight we face the very same problem just discussed in the previous section: only if the decisive date were the 1 May 2010 (rather than the previous dates of adoption) reference to the CFR would be in conformity with the "settled case-law" mentioned supra.

Most strikingly, however, this view has not been adopted by CJ: right to the contrary, in its famous Judgment of 8 April 2014, joint Cases C-293/12 and C-594/12, Digital Rights Ireland/Kärtner Landesregierung (and likewise in its Judgment of 6 October 2015, C-362/14, Schrems) the Court explicitly measured a Directive adopted on 15 March 2006 and a Decision taken by the Commission already in 2000 respectively not only against the Data Protection

46 That this relationship is - at least apart from public service governed by public law - only a horizontal one, the employer thus lacking completely the former vertical responsibility of a feudal landlord with regard to his subjects, should also be inferred from Article 3 (3) TEU where we read that „[t] he Union shall establish ... a highly competitive social market economy"; cf for the prevailing of the market paradigm in EU labour market law implying right from the beginning that employees are best served by their ability to move themselves, i.e. to make best use of the competition among employers on the labour market, Barnard (2011), 642 et seq. It may, however, very well be that just the subsequent aim „at creating" straitforwardly „an integrated European labour market ... rather than correcting its outcomes in line with" "more traditional“ "political standards of social justice" (cit Barnard, ib, 645; emphasis added) worked in the opposite direction (as it is nowadays the case in particular with Article 3 [1a] of Directive 96/71/EC as amended by Directive [EU] 2018/957 [OJ L 173, 16]), thus blurring the border and charging enterprises again directly with the implementation of social policy goals even without any underlying collective agreement (see next $\mathrm{fn}$ ), at least not with one in the bargaining of which the respective enterprise had been represented.

47 Private autonomy implies that - at least within reasonable limits and provided an equal footing - the contracting parties are free to agree on the elements of their contract. Hence, apart from purely synallagmatic elements, also other considerations may gain ground, in particular as a result of collective bargaining between the social partners (see, e.g., infra fn 65).

That is also why it is - in both directions - inappropriate a limine to compare régimes applied in the public service (of EU or in Austria) regarding "family benefits" or allowances of living costs with measures of general social policy. 
Directive, but also against fundamental rights enshrined in the CFR ${ }^{48}$ (at least, as it was the case in the second Judgment, by reading secondary law „in the light of Articles 7, 8 and 47 of the Charter ..." ${ }^{49}$ ). While being perfectly true that neither the Judgments nor the Opinions pondered on this problem of the applicability of the CFR ratione temporis ${ }^{50}$, it may, in this context, suffice to have established that, apparently, Article 24 CFR would at any rate bear relevance for the $\mathrm{CJ}$ also with regard to regulations here at issue. ${ }^{51}$

\subsubsection{Conclusion}

Also from a fundamental rights perspective the current regime of family benefits (relating them in first line to the migrant worker instead of directly to the child) is, most probably, outdated in the post-Lisbon world.

\subsection{Compatibility with Article 9 TEU/Article 20 (1) TFEU?}

\subsubsection{The former „core principle“ and its subsequent counterweight}

As already put forward at length about ten years ago ${ }^{52}$, the former „core principle“ ("Leitmotiv") of the EC Treaty, the prohibition of "any discrimination on grounds of nationality", although still forming part even of post-Lisbon EU primary law ${ }^{53}$, has been counterweighted ${ }^{54}$ already by Article 2 point 9 of Part One of the Treaty of Amsterdam inserting a clarification ${ }^{55}$ added to the

48 Cf Digital Rights Ireland/Kärtner Landesregierung, points 32 et seq (the heading right before point 32 runs: „Interference with the rights laid down in Articles 7 and 8 of the Charter").

49 Cit Schrems, ruling No 1; cf also points 67, 73, 78, 99.

50 One argument in favour of the Court's implicit position could be found in the fourth paragraph of the preamble to the CFR where we read that the purpose of the Charter was not to create new law but only to make already existing one "more visible".

$51 \mathrm{CF}$, however, in the same vein ECJ's Judgment of 11 July 2002, C-224/98, D'Hoop, point 25 („The provisions on citizenship of the Union are applicable as soon as they enter into force. Therefore they must be applied to the present effects of situations arising previously "), still reproduced in CJ' s Judgment of 21 December 2011, Joined Cases C424/10 and C425/10, Ziolkowski/ Szeja, point 58).

52 See Balthasar (2011), 44, $51-75$.

53 Cf not only Article 18 TFEU, but also Article 21 (2) CFR.

54 The formal link enabling the coexistence of these two opposite principles - which fact, by the way, excludes now a limine an „absolute" understanding of the former "Leitmotiv", as had indeed been argued before (cf "Balthasar [1998], 160 et seq, referring to $v$. Bogdandy's then given overview in fn 58, and to ECJ's Judgment of 12 February 1985, C-293/83, Gravier, points 12 et seq; see in more detail infra section III/C) and, apparently, is still maintained by Obwexer (2019), 969 - is provided by the clause „without prejudice to any special provisions contained [in the Treaty/-ies]" forming part of Article 21 (2) TFEU and all its predecessors, back to Article 7 (1) EC Treaty (original version). What is more, "without prejudice" stipulating the prevalence of "any special provision", the former "Leitmotiv" itself now admits its subordinate role with regard to the role of the "national citizenship". When stating this we do not ignore that CJ still long after Amsterdam (in fact, this case-law - which might have been an appropriate interpretation of Article 8 of the EC Treaty [Maastricht version] did only start after Amsterdam [!], see Judgment of 20 September 2001, C-184/99, Grzelczyk, point 31; neither Shaw [2011], 576, nor Obwexer, ib, 958, 964, do cite a more ancient judgement) failed to give credit to this clear change of primary law when ruling that "the status of citizen of the Union is destined to be the fundamental status of nationals of the Member States" (cit Judgment of 26 February 2015, C-359/13, Martens, point 21; Judgment of 2 June 2016, C-233/14, Commission/Netherlands, point 75; Opinion of 10 May 2016, delivered in case C-182/15, point 36). Having, however, not found more recent examples, this negative fact could indeed indicate recently increased caution of the CJ triggered perhaps by the step back carried out by the Judgement of 11 November 2014, C-333/13, Dano, points 61 et seq (cf Obwexer, ib, 966 et seq).

55 When reading in particular point 63 of the Opinion given by GA Léger in C-214/94, Boukhalfa („If all the conclusions inherent in that concept are drawn, every citizen of the Union must, what- 
definition of the "Citizenship of the Union" stating that this "shall be additional to and not replace national citizenship." ${ }^{56}$

\subsubsection{Synthesis}

When applying this insight to the assessment of the regulations here at issue it seems that a fair balance between these two opposite principles ${ }^{57}$ would require - quite alongside what $\mathrm{CJ}$ had said (though not motivated properly) in $D^{D} 0^{58}$ - to differentiate ${ }^{59}$ between (i)the function of citizenship of the Union to "open doors", i.e. to entitle a national of one Member State to make best use of the freedoms of the single market, or to take residence even without such a purpose in another Member State ${ }^{60}$, (ii) the function of domestic nationality to provide the necessary support, in particular when it comes to the allocation of financial ressources of a Member State ${ }^{61}$ which, belonging to this

ever his nationality, enjoy exactly the same rights and be subject to the same obligations"; emphasis added) we might be inclined to conclude that the Masters of the Treaties had exactly in mind to negate Léger's far reaching consequences; most remarkably, Obwexer (2019), 958, although referring to this Opinion, apparently fails to see this correlation. CF, however, also infra section III/D.

56 Cit Article 9 third sentence TEU and Article 20 (1) third sentence TFEU: Article 17 second sentence of the EC Treaty (Amsterdam version) had, only slightly different: „Citizenship of the Union shall complement and not replace national citizenship."

Most strikingly, CJ did not even make use of this amendment when restricting its original formula in Dano (see previous fn but one); hence the (most reasonable) reasoning there lacks any primary law argument. But also doctrine has up to now shown remarkable reluctance to take notice of this primary law change: so we find no reference at all to the sentence cited in the main text (enshrined twice in the Treaties!) in the comments of Kilpatrick (2014), Hölscheidt (2019a) or Köchle (2019) to Article 21 (2) CFR; Obwexer (2019). Not even Edward/Lane (2013) who stress the "derived", even "parasitic" (!) nature of the status of a Union citizen (point 8.06) reconcile this insight with the traditional non-discrimination doctrine reproduced some pages before (cf points 8.02 - 8.04), whereas Shaw while indeed addressing the wording explicitly (ib, 598 et seq; emphasis added) remains dogmatically remarkably vague, although referring "that" it was meant by the Masters of the Treaties to "reinforce ... that EU citizenship... cannot detract from national citizenship" (which finding can be easily understood in the sense that Member States' responsibilities with regard to their own citizens may not be diminished by the additional status of a Union citizen).

57 See Balthasar (2011), 64 et seq, in particular 67 et seq.

58 See supra fns $54,56$.

59 In contrast to the ECHR Article 1 of which clearly defines (alongside the criterion of „jurisdiction ") which State is the addressee of a human rights obligation, Article 51 CFR lacks such a provision. This lacuna can, however, be filled exactly by referring to the sentence just cited in the main text. Consequently, the main addressee also with regard to fundamental rights enshrined in the Charter is always the citizen 's own Member State (with in principle unlimited competence), whereas obligations of another Member State need a specific reason (either, in particular with regard to rights covered by Article 52 (3) CFR, Article 1 ECHR or a specific link to the Treaties) and are are always limited in scope.

60 This function is perfectly met by Articles 7 and 10 of Regulation (EU) No 492/2011.

61 This crucial question (why it should be solely the host Member State's task, not primarily the home Member State's to facilitate the position of a Union citizen aiming at taking advantage of the freedoms of the single market) was still left open in ECJ's reasoning in its Judgments of 22 February 1990, C-228/88, Bronzino (point 12) as well as of 6 October 1995, C-321/93, Martinez (point 21), apparently, answered - in the direction contrary to Pinna I (see infra section 3.1 and 3.2)- by the Masters of the Treaties in Amsterdam and Lisbon (and, finally, accepted, although in a dogmatically still deficient way, by CJ in Dano [fn 54]). 
State's property, are, at least predominantly, destined to be used to the benefit of the respective State's members, i.e. its nationals. ${ }^{62}$

\subsubsection{Conclusion}

From that perspective, however, it would be hard to see why a Member State where a carer of a child resides should be responsible for this child at all even in case where neither the carer nor the child are nationals of that Member State and, furthermore, the child does not even reside in that Member State. Most interestingly, however, despite the understanding of this regulation by the Commission, we will see (infra in section 4.2) that this regulation indeed contains elements fully compatible with the perspective presented here.

\subsection{Compatibility with the „principle of equal treatment “}

\subsubsection{The general principle}

According to settled case-law of $\mathrm{CJ}$, the principle of equal treatment (since Lisbon also enshrined in Article 20 CFR) „requires that comparable situations must not be treated differently and that different situations must not be treated in the same way unless such treatment is objectively justified. " ${ }^{03}$

\subsubsection{The application to the specific case at issue}

In my view, Article 7 of the Founding Regulation cited supra infringes exactly this duty to differentiate ${ }^{64}$ not only with regard to the examples already mentioned supra (2.2.1 and 2.3.3), but also when compulsorily prohibiting any reduction of benefits, according to the actual residence of family members the support of whose living situation is the very aim of the "benefit" at issue:

In sharp contrast to synallagmatic parts ${ }^{65}$ of a salary (wage/remuneration) or even of an insurance system (with regard to unemployment, illness or oldage pension) predominantly based on individual contributions ${ }^{66}$, the granting of "benefits" is not at all dependent on the individual performance (output,

62 To this reasoning two primary law based arguments may be added:

(i) That financial solidarity among Member States (as well as betwen the Union as a whole and Member States) is limited has been explicitly enshrined in Article 125 TFEU (afterwards only narrowly extended by Article 136 (3) TFEU); also separate action of Member States is limited, cf CJ's Judgment of 27 november 2012, C-370/12, Pringle, points 135 et seq).

(ii) Provisions as Article 43 TEU or Article 126 (1) TFEU or Decisions as those based on Article 311 TFEU (cf in particular Article 2 (b) of Council Decision 2007/436/EC, EURATOM) would be distorted if substantive secondary legislation were free to charge Member States with additional financial burdens.

63 Cit Judgment of 28 November 2019, C593/18 P, ABB, point 83 read in conjunction with point 84.

64 It may well be that this duty sometimes is neglected; cf, parte pro toto, Obwexer (2019), who, after having correctly reproduced the full formula $(957)$ concludes: „Daraus resultiert ganz allgemein ein Verbot unsachgemäßer Differenzierung", thus omitting completely the complementary half (the prohibition given emphasis in the main text).

65 These parts are governed by the principle of "iustitia commutativa“.

66 Obviously in every insurance system an aleatory moment (whether the payer of contributions will ever receive any equivalent in return) is inherent; but if the conditions for claiming are met the provision of the equivalent follows the paradigm of synallagma. 
outcome) of the recipient, but of his/her specific need. ${ }^{67}$ So Commissioner Thyssen was simply wrong when invoking the principles of "fairness and equal treatment" as an argument against "indexation“, while exactly the opposite is true:

When the essential yardstick is the actual need, then we have to assess (measure) this need and to grant the help (,benefit ") according to the actual amount of this need. Put it that way, it would run directly counter this principle of equal treatment to treat different living costs "in the same way". ${ }^{68}$ Apparently exactly this view was also taken by the European Council (and the European Commission!) when assessing in February 2016 that indexation according to the "Member State where the child resides" is "fully compatible with the Treaties."

\subsubsection{Further arguments}

In this respect it is really telling that the Commission now argues ${ }^{69}$ that "The fact that another Member State is considered to have lower cost of living than Austria is of no relevance for a benefit, which is paid out as a lump sum and is not linked to the actual cost of maintaining a child."

Because on the one hand the Commission seems to admit that if the benefit were actually "linked to the actual cost of maintaining a child" the Austrian position were correct also from an EU perspective; on the other hand the Commission seems to underestimate the needs of legislation, in particular in a democratic state, being not only under technocratic pressure of standardizing, but also of applying rather an egalitarian yardstick, in particular when it comes to benefits which are addressed to hugh parts of the population.

So the pure fact that the Austrian family benefit is not shaped individually in each particular case is not enough to show that there is no link whatever to the specific needs of families living in Austria.

Even if, however, the Commission's finding were true ${ }^{70}$, exactly the opposite conclusion had to be drawn, the principle of equal treatment (forming part of Austrian national law as well as of EU law) requiring the proper adjustment of the benefit (as stipulated by the Commission itself in early $2016^{71}$ ), not to aggravate the discrepancy between the "lump sum" and the factual situation.

67 These parts are governed by the principle of "iustitia distributiva“. A well-known example is the "individual right to parental leave" enshrined in Clause 2 (1) of the "Framework Agreement" of 18 June 2009 put into effect by Article 1 of Council Directive 2010/18/EU of 8 March 2010, OJ L 68,13 , which entitles everybody "on the grounds of the birth or adoption of a child to take care of that child ...": On the one hand, nobody can make use of this right who is not in the specific position mentioned; on the other hand, in the whole Agreement synallagmatic parts play only a minor role (cf in this regard mainly Clause 3 [b]).

68 From this perspective it does not help either that - as Commissioner Thyssen put forward - all recipients payed taxes and contributed to the social insurance system: this is also the case with employees (self-employed persons) who have no family at all to take care of and, thus, have no right at all to any "family benefit".

69 See supra section 1.2, but also, for the source of this idea, infra section 3.2 .

70 See, however, in more detail infra section 4.1 .

71 See supra section 1.3. 


\subsubsection{Conclusion}

It is not the Austrian position, but, in contrast, the one taken by the Commission, which infringes the principle of equal treatment - if, correctly, this principle is not understood in the way Procrustes did (i.e. treating different situations alike) but, right to the contrary, as a binding commandment to differentiate properly between different situations: i.e. treating synallagmata (salaries/insurance claims, following the paradigm of iustitia commutativa) and benefits meant to cover actual need (following the paradigm of iustitia distributiva) not alike, but differently.

\section{The flash back}

\subsection{Article 40 Regulation (EEC) No 3, Article 73 Regulation (EEC) No 1408/71 and ECJ's Judgment of 15 January 1986, Case 41/86, Pinna I}

Already in the very first chapter of our story, we find a model quite similar to the currrent Austrian indexation model ${ }^{72}$, „Article 40 of Regulation No 3 of the Council of the EEC of 25 September 1958 concerning social security for migrant workers ..." ${ }^{173}$ having „provided that: 'A wage-earner or assimilated worker who is employed in the territory of one Member State, and has children who are permanently resident or are being brought up in the territory of another Member State, shall be entitled, in respect of such children, to family allowances according to the provisions of the legislation of the former State, up to the amount of the allowances granted under the legislation of the latter State'."74

Although „13 years later Regulation 1408/71 ${ }^{75}$ recast that provision“76, this recast was not a general one: Instead, „Article 73 (1) of Regulation No 1408/71 provide[d] that: 'A worker subject to the legislation of a Member State other than France shall be entitled to the family benefits provided for by the legislation of the first Member State for members of his family residing in the territory of another Member State, as though they were residing in the territory of the first State" ", whilst for workers subject to French legislation" - and thus, as we may fairly safely assume, for a quite considerable subset of workers posted in the then European Economic Community the former regime was kept. $^{77}$

72 Although it is true, from a mere technical point of view, that the Austrian indexation depends on a decision of Austrian legislation only, whereas the former model of Regulation No 3 combined the legislation of two Member States, the underlying ratio: to meet the actual need - is the same (under the premiss that national legislation is in the best position to assess the real amount of need on its own teritory).

73 OJ of 16 December 1958, 561.

74 Cit Opinion delivered in Pinna l, point 3 (we make here use of this quasi-official translation the original text having not been published in English; emphasis added).

75 OJ L 149 of 5 July 1971, 2.

76 Cit Opinion delivered in Pinna l, point 3.

77 Article 73 (2) reg cit ran: „A worker subject to French legislation shall be entitled, in respect of members of his family residing in the territory of a Member State other than France, to the family allowances provided for by the legislation of such Member State; the worker must 
This "dual system"78 - and, thus, the original régime with regard to workers posted ${ }^{79}$ in France ${ }^{80}$ (asted unaffected (though not fully undisputed ${ }^{81}$ ) untilECJ's Judgment of 15 January 1986, Case 41/84, Pinna I, by which Article 73 (2) reg cit was declared „invalid in so far as it preclude[d] the award to employed persons subject to French legislation of French family benefits for members of their family residing in the territory of another Member State." Still in the proceedings before the Court, however, not only the French government, but also the Commission and the Council firmly defended the conformity of the contested provisions with EEC primary law, while it was only the Advocate General (of Italian nationality) who, fully in line with the Italian claimant ${ }^{82}$ of the main proceedings and the Italian (and Greek) government, considered the principle enshrined in Article 73 (2) reg cit as such as well as discriminatory and as lacking sufficient justification.

The Court, however, shared this view of the Advocate General, finding not only that the difference made in this provision between France and the other Member States (i.e. the "dual system") was contrary to the Treaty's aim" ${ }^{83}$, but also that it amounted to a "covert discrimination. ${ }^{184}$

But even then the story had not yet come to an end: it needed a second judgement (of 2 March 1989, Case 359/87) to secure compliance of French administration with the régime of Article 73 (1) reg cit. ${ }^{85}$

satisfy the conditions regarding employment on which French legislation bases entitlement to such benefits."

78 Cit Opinion delivered in Pinna l, point 3.

79 For the formal applicability of this provision also with regard to French nationals see infra text by fn 85 .

80 For the close vicinity of the current Austrian with the former French approach cf also supra fn 1.

$81 \mathrm{CF}$ Opinion delivered in Pinna I, point 3: „Member States themselves considered that the resultant dual system should be superseded, and in Article 98 (now Article 99) of Regulation No $1408 / 71$ they determined that within two years the Council should, on a proposal from the Commission, take steps to amend it. In the result, the Commission played its part: it submitted an initial proposal on 10 April 1975 (Official Journal C 96, p. 4), which was followed on 15 January 1976 by the submission to the Council of a second proposal taking into account the amendments suggested by the Economic and Social Committee (Official Journal C 286 of 24 September 1975, p. 19) and by the European Parliament (Official Journal C 257 of 14 October 1975, p. 10). The proposal recommended that there should be a single system for the grant of family benefits and that the general criterion for coordination to be adopted to that end should be the law of the State in which the worker was employed. That proposal remained on the agenda for several Council meetings and was most recently considered at the informal Council meetings held in September and November 1983. Yet again, however, it was not possible to come to a unanimous decision in accordance with Article 51 of the Treaty. $5^{\prime \prime}$.

82 This appearance of bias would better have been avoided, „in accordance with the adage 'justice must not only be done, it must also be seen to be done'" (cit - in another context Opinion delivered in Atanas, point 78; apparently, the adage dates back to High Court England \& Wales' Judgement of 9 November 1923, Rex v Sussex Justices, Ex parte McCarthy. .... a long line of cases shows that it is not merely of some importance but is of fundamental importance that justice should not only be done, but should manifestly and undoubtedly be seen to be done")).

83 Cf points 21 et seq.

84 Cf point 23.

85 The subsequent cases Bronzino and Martinez, both with regard to Germany (and in favour of again an Italian [C-228/88] and a Spain [C-321/93] worker respectively posted abroad), however, indicate that it was not only the French administration which opposed the strict line of Pinnal. 


\subsection{The Advocate General's arguments in Pinna I}

By contending itself to state the obvious (that the provision at issue, although formally applicable also with regard to French nationals, was „by no means equally important for that category" ${ }^{\prime \prime 6}$ ), the Court only proved the element of "covert", but failed to provide any argument why the contested régime discriminated against workers whose children reside abroad or, to put it differently, why it was not even permitted, not to speak of beeing mandatory, to apply the legislation of the state of residence of the family members for the shaping of the appropriate amount of family benefits. When, therefore, consulting the Opinion for guidance, we find indeed a couple of arguments, the quality of which shall be discussed here in detail:

- Quite convincing (at least in the pre-Lisbon era) is, in my view, only the hint that by virtue of other provisions French law family members of a French national staying abroad could still benefit from the full amount of the allowance paid in France. ${ }^{87}$

- Already much less convincing are, however, the arguments completing the assessment of "covert discrimination":

- „[i]n reality" family benefits „in particular" were not tailored „specifically and directly to the cost of maintaining a family“, but „an element supplementary to basic pay"

- as also "tax deductions for maintenance of dependants"had to be taken into account, „[i]f the criterion of the country of residence were applied the worker would run the risk of paying tax in full while ... receiving lower levels of benefit." 88

Even if we refrain from leaving aside a limine the first argument due to the fact that, if taken seriously, it would deprive the term "family benefit" of any reasonable meaning ${ }^{89}$, this first argument would devaluate the second one: because, even when "family benefits" paid by a specific State are meant to compensate in a broader sense not only for a level of wages felt to be inappropriately low, but also for deficiency of specific tax reductions, this State will, when assessing the situation, most probably take into account the "cost-of-living situation" in its own territory, thus not targeting the situation of a posted worker whose family lives abroad.

\section{Cit Pinna l, point 24.}

87 Cf point 6 B. If that were true French law would indeed favour its own nationals, treating them better than foreigners exactly in the situation that family members reside abroad. While such additional care for the nationals of a Member State may now be founded in Article 9 third sentence TEU/Article 20 (1) third sentence TFEU (see supra section 2.3), the assessment was, most probably, different before the creation of these provisions.

88 Cf point 7.

89 Even if the reference made in the Opinion to political practice (that, „as actually happened in Italy", "a given State offsets the low level of wages ... by sharply increasing family benefits" [cit point 7]) were true that specific political practice could only be categorized as an abuse, for that reason alone not appropriate to serve as a premise for further legal reasoning. So the fact that the European Commission when referring the most recent Austrian case to CJ explicitly takes up this argument (see supra section 1.2) indicates the lack of better arguments and, thus, the inner wekness of the Commission's position. 
Although we may understand the then preference for the State of "locus laboris" as the relevant reference ${ }^{90}$, it seems to be outdated today in several respects:

- On the one hand, increase of double income parents (due to several reasons, among them female emancipation) increases the risk that there is, with regard to family benefits, not only one, but (at least) two loci laboris in two different Member States, while permanent residence of children is much more likely to be located only in one Member State

- On the other hand, free movement within EU territories is, already since Maastricht, no longer restricted to "workers "or any other form of professional activity, but open to all citizens of the Union as such, irrespective of any other element. Economically inactive citizens, however, lacking a "locus laboris", there is, with regard to them, no other "choice" ${ }^{\prime 91}$ than to refer to the State of residence (or, horribile dictu, of nationality). In this case, however, it is not only hard to see why, with regard to family benefits, the primordial reference should not be the State of reference where the family members reside (the nationality of which they have), but that of a pater (or mater) familias living in splendid isolation apart from his/her family; what is more, keeping for posted workers the responsibility of the "locus laboris"would mean to reintroduce exactly that sort of a "dual system" then rejected in Pinna I.

So, even if one could understand the reasoning of the time when Pinna / was delivered, subsequent change of the factual as well as of the primary law situation seem to require nowadays the opposite assessment.

Finally, even if still in 1986 a court (or, in our case, an advocate general) were in the position to downsize, quite relaxedly, the financial implications of a specific interpretation of EU law for a specific Member State ${ }^{92}$, the language of Dano ${ }^{93}$ is now a different one. ${ }^{94}$

\subsection{ECJ's Judgment of 12 February 1985, C-293/83, Gravier, and its offspring}

Pinna I is by no means the only judgement where ECJ tempted to establish a rigid régime of disregard of factual cross-border differences, piling up all responsibility of facilitating the mobile citizen's situation solely on the host Member State: A quite famous example of this species being Gravier ${ }^{95}$, we see, however, also the inherent limits of such an approach:

90 Cf Opinion in Pinna l, point 5.

91 Cf Opinion in Pinna l, point 6 A.

92 Cf Opinion, point 7: „... the finances of the French Republic do not seem to be threatened to such an extent as to warrant a special rule ..."

93 See supra fn 54.

94 Cf points 71 (,to prevent such persons from becoming an unreasonable burden on the social assistance system of the host Member State"), 74 .

95 Despite the factual differences between the situation of home and guest students pointed out by the Belgian (federal and self-government) authorities (point 12) and disregarding also the "concerns" expressed by the Danish and the UK government (point 16) ECJ reduced the problem of providing State infrastructure (having to be financed either by taxes or by indebt- 
Still 25 years later, the very same question (in essence, with only superficial modifications) was again referred to the Court, by the same country and by another one, and CJ had this time at least to modify somewhat its former, fully intransigent position. ${ }^{96}$

\subsection{Conclusion}

When suming up we realize that even in the merry old days of formally undisputed reign of the "Leitmotiv" it was more often than not mitigated (Article 40 of the Regulation [EEC] No 3 or circumvented (Article 73 of the Regulation [EEC] No 1408/71), whereas a rigid execution of the principle of non-discrimination on grounds of nationality had to be either based on a rather doubtfu ${ }^{97}$ or at least now outdated ${ }^{98}$ reasoning (Pinna $)$ or raised problems not to be overcome for decades (Gravier). ${ }^{99}$

So when assessing this background - the poor quality of the core arguments of what is still nowadays the Commission's position even under the pre-Amsterdam paradigm - we understand perhaps better why the Masters of the Treaties felt motivated (and legitimated) to downgrade the bearing of the "Leitmotiv" in the Treaty of Amsterdam - only a decade after Gravier and Pinna by adding explicit limitations. ${ }^{100}$

A fortiori ${ }^{101}$ there is no legitimation whatsoever any more to rely on this caselaw still in the post-Lisbon world.

\section{The Austrian law on „family benefits" measured against the yardstick of the Founding Regulation}

\subsection{The Act of 24 October 1967 (current version) itself}

As already mentioned, this Act is based on the federal competence for demographic policy, enshrined in Article 10 (1) (17) of the Federal constitution (Bundes-Verfassungsgesetz; B-VG). Clearly enough, this policy aim was meant

ment, the liability for both instruments being much more likely borne by nationals and permanent residents than by mere hosts of the respective country) to the - very naïve - difference „that the cost of higher art education is not borne by students of Belgian nationality, whereas foreign students must bear part of that cost" (cit point 14).

96 See in more detail Balthasar (2011) with regard to Belgium [Bressol [C-73/08]) and to the parallel situation in Austria.

97 See supra text after fn 88.

98 See supra text after fn 91.

99 Also Dano (see supra fn 54) might be mentioned in this context because CJ declined, as stated, to enforce the "Leitmotiv" without any valid legal argument, just giving in to common sense (arg „unreasonable“, cf fn 92).

100 While it may very well be that the immediate cause of reaction had been the Opinion of GA Léger referred to supra in fn 55 , we see now the whole background.

$101 \mathrm{Cf}$ the additional arguments rooted solely in the Treaty of Lisbon and mentioned already supra section 2.1 and 2.2 . 
to foster the reproduction of the Austrian population (not that of the EU in general) ${ }^{102}$, understood in a double sense:

- All people residing permanently and lawfully in Austria (carer as well as children) ${ }^{103}$

- Austrian citizens with regard to their children if their link to Austria is still closer than to any other State. ${ }^{104}$

Entitled are not only economically active persons, but everyone, by the sole virtue of either being a carer of a (minor) child ${ }^{105}$ or being an orphan. ${ }^{106}$

That in essence it is the child itself who is the entitled person is shown by paragraph 14 (1), whereby a child after having come of age may claim to obtain the benefit him/herself. However, this modern idea has still not yet been realized perfectly insofar as subparagraph 2 requires the consent of the (former) carer. ${ }^{107}$

The actual amount of the benefit differs also apart from the "indexation" here at issue ${ }^{108}$ in various dimensions (is, therefore, not simply a "lump sum" as the Commission has put it $\left.{ }^{109}\right)$ :

- pursuant to paragraph 5, separate income of a child (maintenance by a spouse included) may bar the access completely

- pursuant to paragraph 8 (1), the benefit depends of the number of children in a family and of their respective age $e^{110}$

- pursuant to paragraph 8 (4), the amount of benefit is increased in case of a disabled child

102Although ECJ had already ruled on 10 October 1978 in Case 237/78, Caisse ... Lille, point 15, that "Regulation No 1408/71 does not make any distinction between the social security schemes to which it applies according to whether those schemes do or do not pursue objectives of demographic policy" (a fact hinted to also in the Opinion delivered in Pinna I, point 7) this specific aspect is now again relevant under the current Regulation (EC) No 883/2004, in particular its Article 70, see infra sections 4.2 and 4.3.

103Cf paragraphs 2 (1), 3 (1), (2), 5 (3).

104Cf paragraph 2 (8), 5 (3).

105 Cf paragraph 2 (1).

106Cf paragraph 6.

107 In principle, however, this consent might be enforced by a civil law court.

108See supra section 1.1 .

109See supra section 1.2 .

$110 \mathrm{Cf}$, however, also paragraphs 2s (2) et seq and 6 respectively, with regard to the conditions required for extending the payment after the child having come of age (until having reached the age of 21 or of 24 at the latest), as well as paragraph 32 et seq, concening a specific aid for babies (dependent on the income of the carer) and paragraph 38d et seq, concerning a "bonus", dependent on the one hand oft he income oft he carer, on the other hand whether the child had been proprerly presented to medical examination. 
- The general benefit is completed ${ }^{111}$ by quite detailed allowances on public transport (only partly full free ride is granted) ${ }^{112}$, free access to school books ${ }^{113}$, special grants in case of individual need. ${ }^{114}$

Contributions for these benefits flow, in a rather complicated way, from several sources; in essence, however, it is partly a specific levy imposed on (industrial and agricultural) enterprises (not, however, directly on employees!), partly a share of general tax revenues. ${ }^{115}$

\subsection{The Regulation (EC) No 883/2004}

While it is true that we start reading in the $16^{\text {th }}$ recital of Regulation (EC) No 883/2004:

„Within the Community there is in principle no justification for making social security rights dependent on the place of residence of the person concerned;" the second part of this recital runs as follows:

„nevertheless, in specific cases, in particular as regards special benefits linked to the economic and social context of the person involved, the place of residence could be taken into account. "

This ambiguity (apparently paying already some tribute to the shift of primary law demonstrated supra in section 2.3) is also present in the operative part of this regulation:

- whereas Article 4 and in particular the abovementined Article 7 as well as Article 11 (3) (a) ${ }^{116}$ and $67^{117}$ speak the language of the first half of recital No 16 ,

- the priority rules enshrined in Article 68 seem to be much more inspired already by the post-Amsterdam/post-Lisbon logic:

- Paragraph 1 lit a of this Article states that „the order of priority shall be as follows:

- firstly, rights available on the basis of an activity as an employed or self-employed person,

- secondly, rights available on the basis of a pension and

- finally, rights obtained on the basis of residence; "

\footnotetext{
111 Clearly enough, by its very nature at least the allowances on ride and school books are confined to children atttending a school (or an apprenticeship) in Austria.

112Cf paragraphs 30a et seq.

113 Cf paragraphs 31 et seq.

114Cf paragraphs 38a et seq.

$115 \mathrm{CF}$ in detail paragraphs 39 et seq.

116 Article 11 (2) continues to favour the principle of the prevalence of (as GA Mancini put it in Pinna I) the "locus laboris" (see supra fn 91; for objections based on the current state of Union law see supra section III/B after the mentioned fn).

117 Pursuant to this provision „a person pursuing an activity as an employed or self-emploey person in a Member State shall be subject to the legislation of hat Member State; ..."
} 
- lit b (iii) of this Paragraph adds that „in the case of benefits payable by more than one Member State on the basis of residence" it is "the place of residence of the children" which matters.

- Paragraph 2 excludes explicitly any obligation of even only paying a "differential supplement" „for children residing in another Member State when entitelment to the benefit in question is based on residence only". In addition, pursuant to Article 70 (1) - (3) reg cit its Article 7 and all „special provisions concerning the various categories of benefits" of Titel III shall not apply to "special non-contributory cash benefits which are provided under legislation which, because of its personal scope, objectives and/or conditions for entitlement, has characteristics both of the social security legislation ... and of social assistance", are intended to provide“ inter alia "supplementary, substitute or ancillary cover against the risks covered by the branches of social security referred to in Article 3 (1), and which guarantee the persons concerned a minimum subsistence income having regard to the economic and social situation in the Member State concerned" and "where the financing exclusively derives from compulsory taxation intended to cover general public expenditure and the conditions for providing and for calculating the benefits are not dependent on any contribution in respect of the beneficiary ..." provided that the respective benefit is "listed in Annex X".

\subsection{The Austrian Act measured against the yardstick of Regulation (EC) No 883/2004}

When carefully ${ }^{118}$ assessing the Austrian legislation (section 4.1) against the yardstick of the Regulation (section 4.2), one could be tempted to qualify the Commission's referral as not much more than a veritable "tempête dans un verre d'eau":

- The Austrian benefits - at least in the category at issue (claim of a non-Austrian citizen of the Union living in Austria for obtaining Austrian family benefits for children residing in another Member State) depending solely on the criterion of residence (on Austrian territory), it is, on the basis of the priority rules enshrined in Article 68 (paragraph 1 lit a in conjunction with lit $\mathrm{b}$ [iii]) de facto impossible that Austria should ever be the competent State for paying family benefits at all ${ }^{119}$, the more so, when also paragraph 2 is applied.

118As far can be inferred from the reasons given in the abovementioned (fn 22) referring Decision of the Austrian Federal Tax Court (cf p. 16 et seq), Austrian practice

(i) Fails, up to now, to apply Article 68 (2) reg cit

(ii) ignores the specific relationship between Article 53 (1) of the national Act and Article 68 reg cit (see next fn).

119Even Article 53 (1) of the national Act, providing that

(i) nationals of Constracting Parties of the European Economic Area (EEA) have to be treated equally with Austrian citizens

(ii) the permanent residence of a child in the territory of one of the EEA has to be considered as if the child were permanently resident in Austria, does not alter the result, because provision (ii) is bound back to the "accordance with the provisions of EU law", thus yielding to Art 68 of the Regulation. 
Moreover, the Austrian family benefits fullfilling all substantive requirements of Article 70 reg cit, only the formal step of inclusion in the Annex X is needed to make the result presented in (i) fully transparent.

Hence, it doesn't matter really whether the "indexation"now at issue is in conformity with EU law or not, because Austria's reaction could always be to cancel the "export" of family benefits almost (i.e. with regard to non national children residing abroad) entirely.

\section{Conclusion}

In my view, there are several serious flaws of the Regulation (EC) 883/2004, in particular when applied under the regime of the Treaty of Lisbon, due to mainly three reasons:

- inappropriate (over-simplified) application of the „principle of equal treatment ", by one-sided emphasis on the first element (prohibiton of treating comparable situations differently) and, correspondingly, neglecting the second element (prohibiton of treating different situations "in the same way")

- neglection of the reestablished importance of the „nationality“of a Member State

- discrepancy to Article 352 TFEU and to Article 24 EUCFR.

These elements taken together suffice to recommend that the European Commission, as already proposed in February 2016, although then only in the context of avoiding "Brexit", fulfills its promise to come forward with a proposal to amend the Regulation, in order to bring it in conformity with the principle of equal treatment as well as with other restrictions of current primary law just mentioned. ${ }^{120}$

On the other hand, already the current Regulation is much more in line with current primary law than one would have guessed at first sight; consequently, it is not so much the Regulation itself, but an inappropriate domestic interpretation (most probably triggered by the Commission's approach) which hinders Austria to minimize her obligations with regard to children of other than Austrian nationality living abroad.

This final finding is even more strange, showing the hugh gap between EU law as it is presumed to be in many parts even of Austrian academia ${ }^{121}$ and in EU central institutions (in particular the European Commission) and as it really has been made quite recently by the Masters of the Treaties as well as by the ordinary legislator. This gap needs to be bridged very soon; otherwise we risk

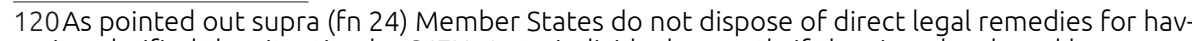
ing clarified the situation by CJEU. As to individuals: exactly if the view developed here were correct a claim for family benefit had to be lodged before an Austrian court but would, after this court having referred to CJEU, not be successful in substance. To rely on such a personal sacrifice (for the higher sake of the EU legal system) does not seem to be fair.

121 See supra text by fns $4 \mathrm{f}$ and fn 22. 
such a bulk of subsequent misunderstandings or of talking so often at cross purposes that in the end the Union itself could be on the ropes. ${ }^{122}$

122Apparently the lessons told by „Brexit“: that too rigid a centralization on EU level/too strongly erasing the importance of nationalities of the respective Member States/too heavily shaping the financial burdens of the "netto payers" may provoke the full exit of Member States were not yet learnt (or, even, the wrong conclusions are drawn by EU central institutions: that now, after Brexit, none of the concessions made by the European Council and the European Commission [see supra section 1.3] are necessary any longer with regard to other Member States).

Hence, the sad story is going on: a most recent telling writing on the wall is in this regard the judgement of Germany's Federal Constitutional Court of 5 May 2020, 2 BvR 859/15 inter alia, assessing a CJ's judgement being null and void due to

(i) excession of competences („ultra vires"), combined with

(ii) arbitrariness and

(iii) most serious methodic flaws.

This assessment is nothing less than a nuclear bomb in the sphere of intra-EU relations as laid down in Article 4 (3) TEU, putting the character of EU as a "community based on the rule of law" (cit ECJ, Les Verts, point 23) as now explicitly enshrined in Article 2 TEU at stake. 


\section{References}

A New Settlement for the United Kingdom within the Euroepan Union. (2016). Extract of the conclusions of the European Council of 18-19 February 2016, 1, 2016/C 69 I/01, OJ C 69I, 1.

AG Bobek (2018). Opinion of 18 January 2018 delivered in case C-528/16, Confédération Paysanne.

AG Bot (2016). Opinion of 10 May 2016, delivered in case C-182/15, Petruhhin.

AG Bot (2016). Opinion of 23 February 2016, delivered in case C-614/14, Atanas.

AG Léger (1995). Opinion of 14 November 1995, C-214/94, Boukhalfa.

AG Lenz (1988). Opinion of 1 December 1988, delivered in Case 359/87, Pinna II.

AG Mancini (1985). Opinion of 21 May 1985, delivered in Case 41/84, Pinna I.

Austrian Broadcast (ORF). (2019). At <https://orf.at/stories/3142459/>, accessed 3 November 2020.

Austrian Federal Government. Explanatory Memorandum, RV 111 Blg NR XXVI. GP. At<https://www.parlament.gv.at/PAKT/VHG/XXVI/I/I_00111/ fname_692212.pdf, accessed 3 November 2020.

Austrian Federal Tax Court. (2020). Decision of 16 April 2020, RE/7100001/2020.

Balthasar, A. (2017). Die Übertragung von Hoheitsrechten nach der österreichischen Bundesverfassung - Zulässigkeit, Grenzen und Kontrolle. Jahrbuch für Vergleichende Staats- und Rechtswissenschaften, 2016/2017. Baden-Baden: Nomos, pp. 167-211.

Balthasar, A. (2011). „Nichtdiskriminierung und Unionsbürgerschaft“ in einem "Staatenverbund". Zugleich eine Auseinandersetzung mit (vornehmlich) dem Urteil des EuGH vom 13. 04. 2010, C-73/08 (Bressol). ZÖR, 66(1), pp. 41-75.

Balthasar, A. (1998). „Inländerdiskriminierung“ in der EU nach dem EG-Vertrag und aus österreichischer Sicht. ZÖR, 53(2), pp. 143-216.

Balthasar-Wach, A. (2020). Die Justizielle Zusammenarbeit in Zivilsachen am Beispiel von Kindesentführungsfällen innerhalb der Europäischen Union. Wien: Sramek.

Barnard, C. (2011). EU "Social“ Policy: From Employment Law to Labour Market Reform. In P. Craig and G. De Búrca, eds., The Evolution of EU Law. Oxford: Oxford University Press, pp. 541-686.

Benoît-Rohmer, F. (2011). La charte des droits fondamenteaux de l'Union europeénne dix ans après sa proclamation. In W. Benedek et al., eds, European Yearbook on Human Rights. Antwerp et al.: European Academic Press, pp. 25-39.

CJEU. (2019). Judgment of 28 November 2019, C593/18 P, ABB.

CJEU. (2019). Judgment of 10 September 2019, C123/18 P, HTTS.

CJEU. (2016). Judgment of 2 June 2016, C-233/14, Commission/Netherlands.

CJEU. (2015). Judgment of 6 October 2015, C-362/14, Schrems.

CJEU. (2015). Judgment of 3 September 2015, C-398/13 P, Inuit.

CJEU. (2015). Judgment of 26 February 2015, C-359/13, Martens.

CJEU. (2014). Judgment of 8 April 2014, joint Cases C-293/12 and C-594/12, Digital Rights Ireland and Kärtner Landesregierung.

CJEU. (2014). Judgement of 11 November 2014, C-333/13, Dano.

CJEU. (2013). Judgment of 26 September 2013, C-431-11, UK/Council. 
CJEU. (2012). Judgment of 21 December 2012, Joined Cases C-424/10 and C-425/10, Ziolkowski/Szeja.

CJEU. (2011). Judgment of 28 July 2011, C-309/10, Agrana.

De Schutter, O. (2011). The New Architecture of Fundamental Rights Policy in the EU. In W. Benedek et al., eds., European Yearbook on Human Rights. Antwerp et al.: European Academic Press, pp. 107-141.

ECJ. (2002). Judgment of 11 July 2002, C-224/98, D'Hoop.

ECJ. (2001). Judgment of 20 September 2001, C-184/99, Grzelczyk.

ECJ. (2000). Judgment of 4 April 2000, C-269/97, Commission/Council.

ECJ. (1996). Opinion of 28 March 1996, No 2/94.

ECJ. (1995). Judgment of 5 October 1995, C-321/93, Martinez.

ECJ. (1990). Judgment of 22 February 1990, C-228/88, Bronzino.

ECJ. (1989). Judgment of 2 March 1989, Case 359/87, Pinna II.

ECJ. (1986). Judgment of 23 April 1986, Case 294/83, Les Verts.

ECJ. (1986). Judgment of 15 January 1986, Case 41/84, Pinna I.

ECJ. (1985). Judgment of 12 February 1985, C-293/83, Gravier.

ECJ. (1978). 10 October 1978, Case 237/78, Caisse régionale d'assurance maladie Lille.

Edward, D. and Lane, R. (2013). Edward and Lane on European Union Law. Cheltenham, UK, Northhampton, MA, USA: Edward Elgar.

European Council. (2016). Conclusions of the meeting 18/19 February 2016, EUCO 1/16. At <https://www.consilium.europa.eu/media/21787/0216-eucoconclusions.pdf>, accessed 3 November 2020.

European Commission. (2020). Press Release of 14 May 2020. At <file:///C:/ Users/alexa/Google\%20Drive/Fambh/Indexation_of_family_benefits_child_ tax_credit_and_family_tax_credits_Commission_takes_Austria_to_court_ for_discrimination.pdf>, accessed 3 November 2020.

European Commission. (2019). Press Release of 27 November 2019. At <https:// ec.europa.eu/commission/presscorner/detail/en/INF_19_6304>, accessed 3 November 2020.

European Commission. (2019). Press Release of 25 July 2019. At<https:// ec.europa.eu/commission/presscorner/detail/en/IP_19_4253>, accessed 3 November 2020.

European Commission. (2019). Press Release of 24 January 2019. At <https:// ec.europa.eu/commission/presscorner/detail/EN/IP_19_463>, accessed 3 November 2020

Fuchs, C. (2019). Commentary on Article 24 CFR. In M. Holoubek and G. Lienbacher, eds., Charta der Grundrechte der europäischen Union.: Wien, Manz: GRC -Kommentar, pp. 495-509.

Germany's Federal Constitutional Court. (2020). Judgement of 5 May 2020, 2 BvR 859/15 inter alia.

Hölscheidt, S. (2019a and b respectively). Commentaries on Articles 21 and 24 CFR. In J. Meyer, ed., Charta der Grundrechte der Europäischen Union5. Baden-Baden: Nomos, pp. 439-461 and pp. 483-494 respectively.

Irmscher, T. (2019). Grundsatz der begrenzten Einzelermächtigung. In B. Schöbener, ed., Europarecht. Lexikon zentraler Begriffe und Themen. Heidelberg: C.F. Müller, pp. 449-455. 
Kilpatrick, C. (2014). Commentary on Article 21 CFR. In S. Peers et al., eds, The EU Charter of Fundamental Rights. Oxford/Portland, Oregon: Hart, pp. 579-603.

Köchle, C. (2019). Commentary on Article 21 CFR. In M. Holoubek and G. Lienbacher, eds., Charta der Grundrechte der Europäischen Union. GRCKommentar ${ }^{2}$. Wien, Manz, pp. 440-470.

Lamont, R. (2014). Commentary on Article 24 CFR. In S. Peers et al., eds, The EU Charter of Fundamental Rights. Oxford/Portland, Oregon: Hart, pp. 661-691.

Neue Volkspartei/ Freiheitliche Partei Österreichs. (2020). Austrian Coalition Programme „Together for our Austria“. At < https://www.oeh.ac.at/sites/ default/files/files/pages/regierungsprogramm_2017-2022.pdf>, accessed 3 November 2020.

Obwexer, W. (2019). Die Unionsbürgerschaft als revolutionäres Konzept. ZÖR, 74(4), pp. 955-992.

Shaw, J. (2011). Citizenship: Contrasting Dynamics at the Interface of Integration and Constitutionalism. In P. Craig and G. De Búrca, eds, The Evolution of EU Law². Oxford: Oxford University Press, pp. 575-609.

UK England and WalesHigh Court of Justice. (1923). Judgment of 9 November 1923, Rex v Sussex Justices, Ex parte McCarth. At <https://www.bailii.org/cgibin/format.cgi?doc=/ew/cases/EWHC/KB/1923/1.html, accessed 3 November 2020.

Walter, R. (1972). Österreichisches Bundesverfassungsrecht. Wien, Manz: System. 